\title{
Childhood Ovarian Nongerminomatous Germ Cell Tumor
}

National Cancer Institute

\section{Source}

National Cancer Institute. Childhood Ovarian Nongerminomatous Germ Cell Tumor. NCI

Thesaurus. Code C123842.

A nongerminomatous germ cell tumor that arises in the ovary and occurs in children. 